\title{
ASSESSING KNOWLEDGE OF PHYSICAL ACTIVITY BENEFITS IN DIABETIC PATIENTS
}

\section{OCENA WIEDZY NA TEMAT KORZYŚCI PLYNĄCYCH Z AKTYWNOŚCI FIZYCZNEJ WŚRÓD CHORYCH NA CUKRZYCE}

\author{
Jan Junger ${ }^{1,2(A, B, C, D, E, G)}$, Dana Dračková1 ${ }^{1(\mathrm{~A}, \mathrm{D}, \mathrm{E}, \mathrm{G})}$, Alena Buková1 ${ }^{1(\mathrm{~A}, \mathrm{D}, \mathrm{E}, \mathrm{F}, \mathrm{G})}$, \\ Andrea Junger ${ }^{3(\mathrm{~A}, \mathrm{C}, \mathrm{D}, \mathrm{F})}$, Zuzana Kuchelová ${ }^{1(\mathrm{~B}, \mathrm{E}, \mathrm{F})}$ \\ ${ }^{1}$ Institute of Physical Education and Sport, Pavol Jozef Šafárik University in Košice, Slovakia \\ ${ }^{2}$ Faculty of Physical Education, University of Rzeszów, Poland \\ ${ }^{3} \mathrm{X}$-body, Prešov, Slovakia
}

Authors' contribution Wkład autorów:

A. Study design/planning zaplanowanie badań B. Data collection/entry zebranie danych C. Data analysis/statistics dane - analiza i statystyki D. Data interpretation interpretacja danych E. Preparation of manuscript przygotowanie artykułu F. Literature analysis/search wyszukiwanie i analiza literatury G. Funds collection zebranie funduszy
Tables: 0

Figures: 3

References: 28

Submitted: 2020 Jan 15

Accepted: 2020 Apr 30

\section{Summary}

Background. The aim of this work was to examine the awareness of patients with diabetes mellitus (DM) on the importance of physical activity (PA) in the prevention and treatment of their disease.

Material and methods. The survey was completed by 178 respondents ( $47.3 \%$ women, $52.7 \%$ men), of whom 69.1\% were dependent on exogenous insulin. Data was collected in April 2019 via a questionnaire given to patients at the Department of Diabetology and Internal Medicine at the Louis Pasteur University Hospital in Košice, Slovakia.

Results. More than half of the respondents admitted having insufficient information about their health condition, and a similar proportion felt lack of knowledge regarding exercise for their illness. As many as $69.1 \%$ of the patients reported inadequate help by their health care providers with regard to the do's and dont's of their disease, and $41.9 \%$ of respondents reported having no knowledgeable health care provider with whom to share their concerns.

Conclusions. Based on the results obtained, it is concluded that a substantial number of DM patients do not have adequate information about their health condition and how to improve it. On the other hand, nearly two-thirds of participants recognize that regular physical activity (PA) is an option to achieve positive changes.

Keywords: health, diabetes mellitus, physical activity, patients, knowledge

\section{Streszczenie}

Wprowadzenie. Celem pracy było zbadanie świadomości pacjentów z cukrzycą co do znaczenia aktywności fizycznej w procesie zapobiegania ich chorobie i jej leczenia.

Materiał i metody. W badaniu wzięło udział 178 respondentów, z czego 47,3\% stanowiły kobiety, a $52,7 \%$ mężczyźni. $69,1 \%$ badanych było zależnych od insuliny egzogennej. Dane zostały zebrane w kwietniu 2019 r. za pomoca kwestionariusza przekazanego pacjentom na Oddziale Diabetologii i Chorób Wewnętrznych Szpitala Uniwersyteckiego Louisa Pasteura w Koszycach na Słowacji.

Wyniki. Ponad połowa respondentów przyznała, że nie jest wystarczająco poinformowana w kwestii dotyczącej ich stanu zdrowia; podobna liczba ankietowanych odczuwała brak wiedzy o ćwiczeniach w związku z ich chorobą. Aż $69,1 \%$ pacjentów zgłosiło nieodpowiednią pomoc ze strony instytucji świadczących usługi medyczne w odniesieniu do nakazów i zakazów dotyczących ich stanu zdrowia. Ponadto $41,9 \%$ ankietowanych zgłosiło brak wykwalifikowanych pracowników służby zdrowia, z którymi mogliby podzielić się swoimi obawami.

Wnioski. Na podstawie uzyskanych wyników stwierdzono, że znaczna liczba pacjentów cierpiących na cukrzycę nie ma wystarczającej wiedzy co do swojego stanu zdrowia i możliwości jego poprawy. Z drugiej strony prawie dwie trzecie uczestników badania postrzega regularną aktywność fizyczną jako drogę do osiągnięcia pozytywnych zmian.

Słowa kluczowe: zdrowie, cukrzyca, aktywność fizyczna, pacjenci, wiedza 


\section{Introduction}

Increases in diseases and mortality from non-infectious, so-called "civilization diseases", is a major global problem. Mass occurrence of non-infectious diseases is attributed to genetics, but also to a number of external circumstances, processes, and factors, including poor lifestyle habits and absence of physical activity (PA) [1].

Since PA is one of the basic living needs of a person, its importance is not only relevant to healthy individuals, but also populations facing disease and/or disability, perhaps to an even greater extent. This is also true for patients with diabetes mellitus (DM), where PA is not just a highly effective, non-invasive means of treating this health problem, but can also serve to prevent it. As the prevalence of DM increases in a pandemic rate across the world [2-8], recognition of the important preventative role of PA is especially important.

Research has been conducted to determine the place and importance of PA in the prevention and treatment of civilization diseases [9-18]. Accordingly, experts in the American Diabetes Association [19] have published standards regarding the prescribing of PA in DM diseases across various age groups and types of the disease. These generally suggest that children and young people should spend at least 60 minutes a day on PA. Adults with DM should perform PA (of moderate intensity) of at least 150 minutes/week, spread over at least three days, with no more than two consecutive days without exercise. As long as there are no contraindications, it is recommended to add resistance training two times a week.

In accordance with the above recommendations and based on previous findings, the authors [20-23] and others have suggested that intensive training in this population be primarily aerobic, while confirming that combined aerobic and resistance training has the greatest health and performance benefits.

The DM patient has the right to receive the best possible care, including information on how treatment will take place. Before any procedure, treatment, or training regimen, the patient should be properly instructed, leading to a doctor-patient relationship of equality [24]. The attending physician or health care professional is obliged to inform the patient of all the consequences, risks, and actions offered to him/her and also to warn him/ her that if rejected, other complications may occur [25].

A patient who is familiar with his/her health condition may adapt to the situation and actively cooperate with the physician to prevent his/her health from getting worse. The patient also determines to what extent s/ he wants to be informed.

The aim of this paper is to examine the awareness of DM patients on the significance of PA in the prevention and treatment of their disease, as well as determine their understanding of how much and what types of PA should be included in their daily schedule.

\section{Material and methods}

A total of 178 respondents (47.3\% women, 52.7\% men) participated in the study, 69.1\% of whom were dependent on regular exogenous insulin doses. Within this sample, $23.6 \%$ of patients had DM for less than 5 years, $27.3 \%$ for $6-10$ years, $25.5 \%$ for $11-15$ years, $10.9 \%$ for $16-20$ years, and $12.7 \%$ for over 20 years.

Data was obtained in April 2019 from a questionnaire that we personally handed out to every patient at the Diabetes and Internal Medicine Outpatient Department at the Louis Pasteur University Hospital in Košice, Slovakia. Everyone was able to participate, therefore we consider this sample as representative of the population of interest. Doctors and/or directors of the relevant departments agreed with each patient's participation. All participants consented to being part of the research. The study was approved by the UPJŠ Ethics Committee (PJSU-1/0825/17).

For data collection, we used a non-standardized questionnaire that contained 29 questions and was designed to be completed within 20 minutes, under the supervision of an administrator. The questions were aimed at finding out to what extent patients are informed of their illness, whether they are informed on what procedures will be performed in their treatment, what importance they attach to PA in that process, and what they typically include in their daily activities. Most questions were closed-ended, with the option for respondents to elaborate. PA was determined based on patient responses to the International Physical Activity Questionnaire (IPAQ), the Borg Perception Exercise Scale (RPE), and scaled according to the recommendations of the American Diabetes Association [19]. Questionnaire responses were anonymous.

Aftercompleting the questionnaire, therespondentsobtained acolorfulbrochurecontaining recommendations on PA and a healthy lifestyle with regard to their diagnosis. 


\section{Results}

Based on the topic and goal of our work, the priority was the data about awareness of DM patients on the importance and place of PA in their lives. As this is a specific area that has long received very little attention from a societal perspective, we considered it necessary to know the level of general awareness of patients about their disease and treatment. We believe that in the absence of this type of information, it is difficult to develop targeted PA interventions.

Only $43.7 \%$ of respondents agreed that they receive adequate information to help in coping with their health problems, with $36.4 \%$ of patients unable to determine whether the information obtained is correct or not (Figure 1). A similar proportion of respondents (40\%) do not attempt to verify the information they obtain from publicly available sources.

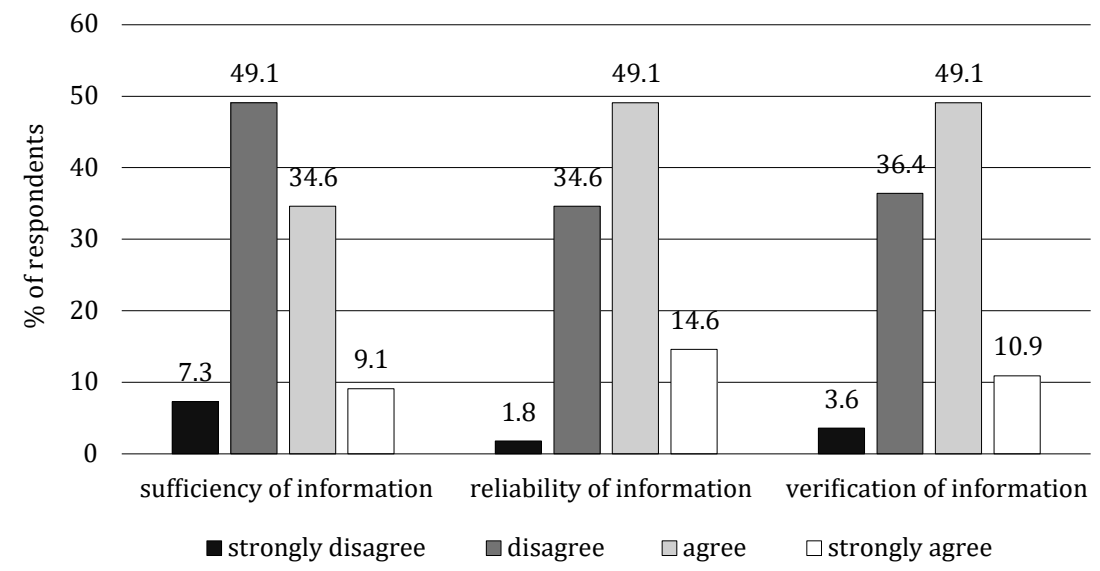

Figure 1. Patients' opinions on the sufficiency and reliability of relevant health information

Family plays an important role in the treatment of patients. Most participants agreed that family and close friends help and provide positive support in managing their disease (Figure 2).

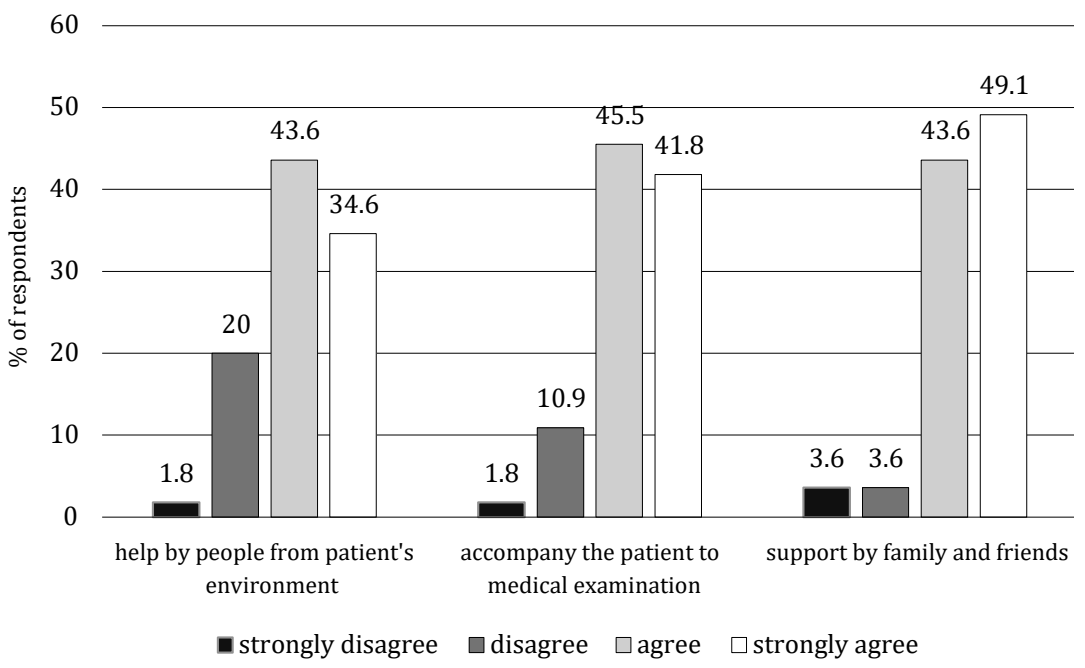

Figure 2. Patients' opinions on the role of family in their treatment

Patient assistance from healthcare providers looks a little less favorable than family and close friends. But even in this case, over half of the patients surveyed (50.6\%) claim to have an accessible healthcare provider with whom they may discuss their health problems, and a little more (58.1\%) report that they have a healthcare provider who knows them well and has sufficient knowledge of their health condition.

On a related note, $12.7 \%$ of patients reported regularly having a problem with understanding written health information, while $38.2 \%$ reported so occasionally, $30.9 \%$ rarely, and $18.2 \%$ of patients reported no problems understanding written information from medical documentation. 
In the second part of this study, we focused on the importance of PA in the prevention and treatment of DM. A majority (69.1\%) of patients reported awareness of the positive benefits of PA in this regard. Specifically, they see its importance in lowering blood sugar (45.5\%) and lowering blood pressure and cholesterol levels (38.2\%). We were therefore interested in what place PA has had in their recent everyday life (Figure 3). Most respondents reported performing PA in household work and employment. But, interestingly, 32.7\% of them also performed some form of sporting activity during the last week. On the other hand, $21.8 \%$ of patients reported that they had not performed any PA during the last week. Because all respondents had DM, it was important to find out their knowledge on the role of physical exercise in relation to their disease. We found it promising that approximately two-thirds of the respondents understand the importance of PA.

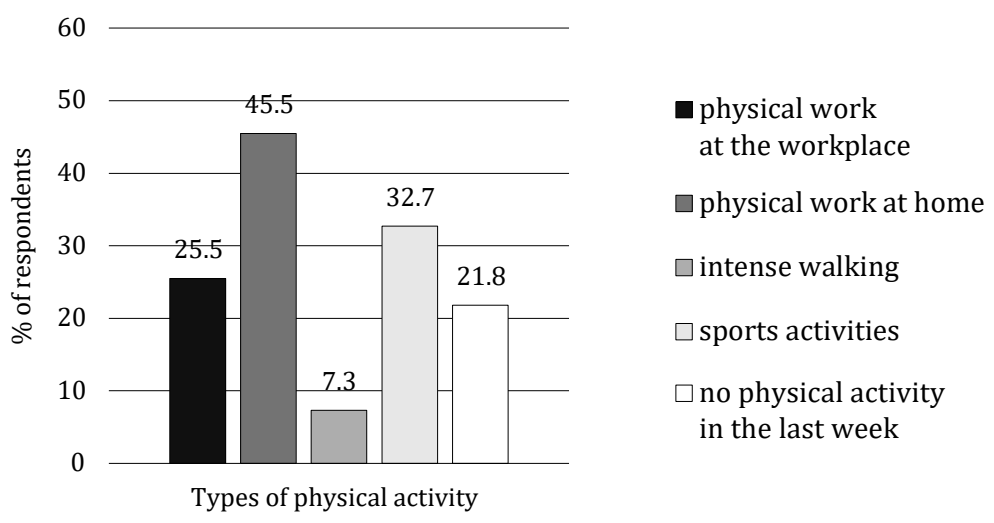

Figure 3. Physical activity performed in the last week

When analyzing the frequency of continuous PA (longer than $30 \mathrm{~min}$ ), we learned that only $1.8 \%$ of patients perform continuous PA every day, 14\% almost every day, 20\% 2-3 times a week, and 27.3\% at least once a week. Approximately one-third of the patients engaged no, or only sporadic, PA.

\section{Discussion}

Healing generally requires positive engagement of the patient. The extent of the patient's engagement in the management and treatment of disease will depend in part on information they have received. We found that less than half of DM patients report receiving adequate information on their health, with a slightly higher proportion reporting receiving information specific to helping cope with DM.

Previous data suggests that outside support in addressing health problems is important to mental and physical well-being. Our results fully support this assumption. Patients in our study relied heavily on their family and acquaintances in addressing their health-related problems, accompanying them at medical examinations, etc.

Healthcare providers are the second, more qualified, part of the patient's environment. We were particularly interested in those providers with whom patients are able to have more in-depth and regular discussions regarding their health concerns. With the current overload on the healthcare system, especially for specialist physicians, it is not surprising that nearly half of the patients surveyed do not have the opportunity to have sufficient interaction with such healthcare providers. These findings are consistent with previous research indicating $41 \%$ of at-risk patients (i.e., family history of DM) report not receiving adequate information from healthcare providers regarding potential health concerns [26]. In non-risk patients (i.e., no family history of DM), however, only $21.3 \%$ reported receiving information on health risks from their treating physician. Most uninformed patients (41.1\%), regardless of risk category, fall into the age group of 35-54 years.

Another goal was to better understand the beliefs of DM patients on the importance of PA in the prevention and treatment of their disease. Almost three-quarters of the respondents know that PA can have a positive impact on their health problems. Yet, most respondents only get PA through physical work at home or in employment. Just one-third said they had also participated in leisure exercise or sport in the last week, which is similar to previous findings [15]. Importantly, physical activity was generally performed at least 2-3 times a week. This was also reflected in the most popular physical activities reported, which were dominated by common work activities. However, more than one-quarter of patients do not enjoy any PA and up to one-third of them have not been active recently. Patients particularly recognize the importance of PA in DM through its improvements on blood sugar control, blood pressure and cholesterol, which is consistent with evidence-based benefits $[9-15,17,20]$. 
The obtained data is consistent with the conclusions of the abovementioned previous research, but similarly to some authors $[27,28]$, we consider it important to improve the awareness of patients with DM on the possible risks, in particular with the help of healthcare providers.

\section{Conclusions}

Over half of the DM patients surveyed report a lack of information on how to cope with their health problems, one-third cannot assess the credibility of information, and even fewer do not even try to verify this information. Family and close friends provide the greatest level of support to DM patients in tackling their health problems, with just over half of healthcare professionals also serving in this role.

Based on this fact, we find it promising that almost two-thirds of the respondents are given information on the importance of regular PA on positive changes in their health status. While, the PA comes primarily in the form of physical work at home and in employment, there is much room for growth in increasing leisure-time physical activity in this population.

\section{Disclosures and acknowledgements}

The study was conducted as part of VEGA grant project No. 1/0825/17 "Recommendations for physical activities of risk groups and their performance in Eastern Slovakia".

\section{References:}

1. Hendl J, Dobrý L., editors. [Health benefits of physical activity, monitoring, intervention, evaluation]. Praha: Nakladatelství Karolinum; 2011 (in Czech).

2. Lébl J, Průhová Š., editors. [The alphabet of diabetes - guideline for children, youth and their parents]. $2^{\text {nd }}$ edition. Praha: Maxdorf; 2005 (in Czech).

3. Halley JA. Exercise as a therapeutic intervention for the prevention and treatment of insulin resistance. Diabetes Metab Res Rev. 2004; 20(5): 383-393. https://doi.org/10.1002/dmrr.505

4. Booth W, Winder WW. Role of exercise in reducing the risk of diabetes and obesity. J Appl Physiol. 2005; 99(1): 3-4. https://doi.org/10.1152/japplphysiol.00386.2005

5. La Monte MJ, Blair SN, Church TS. Physical activity and diabetes prevention. J Appl Physiol. 2005; 99(3): 1205-1213. https://doi.org/10.1152/japplphysiol.00193.2005

6. Gill J, Cooper A. Physical activity and prevention of type 2 diabetes mellitus. Sports Med. 2008; 38(10): 807824. https://doi.org/10.2165/00007256-200838100-00002

7. Sui X, Hooker S, Lee IM, Church TS, Colabianchi N, Lee Ch, et al. A prospective study of cardiorespiratory fitness and risk of type 2 diabetes in women. Diabetes Care. 2008; 31(3): 550-555.

https://doi.org/10.2337/dc07-1870

8. Lee D, Sui X, Church TS, Lee I, Blair SN. Associations of cardiorespiratory fitness and obesity on risks of impaired fasting glucose and type 2 diabetes in men. Diabetes Care. 2009; 32(2): 257-262. https://doi.org/10.2337/dc08-1377

9. Tokmakidis SP, Zois CE, Volaklis KA, Kotsa K, Touvra AM. The effects of a combined strength and aerobic exercise program on glucose control and insulin action in women with type 2 diabetes. Eur J Appl Physiol. 2004; 92(4-5): 437-442. https://doi.org/10.1007/s00421-004-1174-6

10. Sigal RJ, Kenny GP, Boulé NG, Wells GA, Prud'homme D, Fortier M, et al. Effects of aerobic training, resistance training, or both on glycemic control in type 2 diabetes: a randomized trial. Ann Intern Med. 2007; 147(6): 357-369. https://doi.org/10.7326/0003-4819-147-6-200709180-00005

11. Gillison FB, Skevington SM, Sato A, Standage M, Evangelidou S. The effects of exercise interventions on quality of life in clinical and healthy populations: a meta-analysis. Soc. Sci. Med. 2009; 68(9): 1700-1710. https://doi.org/10.1016/j.socscimed.2009.02.028

12. Kirwan JP, Solomon TP, Wojta DM, Staten MA, Holloszy JO. Effects of 7 days of exercise training on insulin sensitivity and responsiveness in type 2 diabetes mellitus. Am. J. Physiol. Endocrinol. Metab. 2009; 297(1): E151-6. https://doi.org/10.1152/ajpendo.00210.2009

13. Colberg SR, Sigal RJ, Fernhall B, Regensteiner JG, Blissmer BJ, Rubin RR, et al. Exercise and type 2 diabetes: the American College of Sports Medicine and the American Diabetes Association: joint position statement. Diabetes Care. 2010; 33(12): e147-67. https://doi.org/10.2337/dc10-9990

14. Sanz C, Gautier JF, Hanaire H. Physical exercise for the prevention and treatment of type 2 diabetes. Diabetes \& Metabolism. 2010; 36(5): 346-351. https://doi.org/10.1016/j.diabet.2010.06.001 
15. Zhao G, Ford ES, Li C, Balluz LS. Physical activity in U.S. older adults with diabetes mellitus: prevalence and correlates of meeting physical activity recommendations. J Am Geriatr Soc. 2011; 59(1): $132-137$. https://doi.org/10.1111/j.1532-5415.2010.03236.x

16. Hordern MD, Dunstan DW, Prins JB, Baker MK, Singh MA, Coombes JS. Exercise prescription for patients with type 2 diabetes and pre-diabetes: a position statement from Exercise and Sport Science Australia. Journal of Science and Medicine in Sport. 2012; 15(1): 25-31. https://doi.org/10.1016/j.jsams.2011.04.005

17. Thent ZC, Das S, Henry LJ. Role of exercise in the management of diabetes mellitus: the global scenario. PLoS One. 2013; 8(11): e80436. https://doi.org/10.1371/journal.pone.0080436

18. O'Hagan C, De Vito G, Boreham CA. Exercise prescription for patients with type 2 diabetes a synthesis of international recommendations: narrative review. Sports Med. 2013; 43(1): 39-49. https://doi.org/10.1007/s40279-012-0004-y

19. American Diabetes Association. Standards of medical care in diabetes. 2014. Diabetes Care. 2014; 37(Suppl. 1): S14-S80. https://doi.org/10.2337/dc14-S014

20. Asano RY, Sales MM, Browne RAV, Vila Nova Moraes JF, Coelho Júnior HJ, Moraes MR, et al. Acute effects of physical exercise in type 2 diabetes. World J Diabetes. 2014; 5(5): 659-665. https://doi.org/10.4239/wjd.v5.i5.659

21. Alvarez C, Ramirez-Campillo R, Martinez-Salazar C, Mancilla R, Flores-Opazo M, Cano-Montoya J, et al. Lowvolume high-intensity interval training as a therapy for type 2 diabetes. International Journal of Sports Medicine. 2016; 37(9): 180-193. https://doi.org/10.1055/s-0042-104935

22. Nouh F, Omar M, Younis M. Prevalence of hypertension among diabetic patients in Benghazi: a study of associated factors. Asian Journal of Medicine and Health. 2017; 6(4): 1-11. https://doi.org/10.9734/AJMAH/2017/35830

23. Jenkins D, Jenks A. Exercise and diabetes: a narrative review. The Journal of Foot \& Ankle Surgery. 2017; 56(5): 968-974. https://doi.org/10.1053/j.jfas.2017.06.019

24. Hošková B. [Informedness of clients/patients and family members] [Internet]. Divize Medical Services: Praha; 2010 [cited 2017 Dec 3]. Available from: https://zdravi.euro.cz/clanek/sestra/informovanostklientu-pacientu-a-rodinnych-prislusniku-449665 (in Czech).

25. Matisová L. [Right for information about the health status] [Internet]. Komora pre medicínske právo MEDIUS: Košice; 2009 [cited 2019 March 5]. Available from: http://www.pravo-medicina.sk/aktuality/28/ pravo-na-informacie-o-zdravotnom-stave (in Slovak).

26. Qureshi N, Kai J. Informing patients of familial diabetes mellitus risk: how do they respond? A cross-sectional survey. BMC Health Services Research. 2008; 8: 37. https://doi.org/10.1186/1472-6963-8-37

27. Tham KY, Ong JJY, Tan DKL, How KY. How much do diabetic patients know about diabetes mellitus and its complications?. Ann Acad Med Singapore. 2004; 33(4): 503-509.

28. Huang ES, Gorawara-Bhat R, Chin MH. Self-reported goals of older patients with type 2 diabetes mellitus. J Am Geriatr Soc. 2005; 53(2): 306-311. https://doi.org/10.1111/j.1532-5415.2005.53119.x 